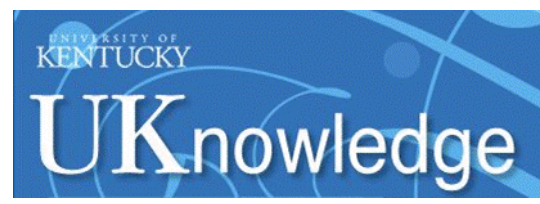

University of Kentucky

UKnowledge

7-1-1999

\title{
Adolescent Violence as Viewed by High School Students
}

Hatim A. Omar

University of Kentucky, hatim.omar@uky.edu

Follow this and additional works at: https://uknowledge.uky.edu/pediatrics_facpub

Part of the Defense and Security Studies Commons, Secondary Education Commons, and the Sociology Commons

Right click to open a feedback form in a new tab to let us know how this document benefits you.

\section{Repository Citation}

Omar, Hatim A., "Adolescent Violence as Viewed by High School Students" (1999). Pediatrics Faculty Publications. 247.

https://uknowledge.uky.edu/pediatrics_facpub/247

This Article is brought to you for free and open access by the Pediatrics at UKnowledge. It has been accepted for inclusion in Pediatrics Faculty Publications by an authorized administrator of UKnowledge. For more information, please contact UKnowledge@lsv.uky.edu. 


\section{Adolescent Violence as Viewed by High School Students}

Digital Object Identifier (DOI)

https://doi.org/10.1515/IJAMH.1999.11.3-4.153

Notes/Citation Information

Published in International Journal of Adolescent Medicine and Health, v. 11, issue 3-4, p. 153-158.

(C)2011 by Walter de Gruyter GmbH \& Co.

The copyright holder has granted permission for posting the article here. 


\title{
ADOLESCENT VIOLENCE AS VIEWED BY HIGH SCHOOL STUDENTS
}

\author{
Hatim A. Omar* \\ Department of Pediatrics, University of Kentucky, Lexington, \\ Kentucky, USA
}

\begin{abstract}
On April 20 ${ }^{\text {th }}, 1999$ two high school students from Columbine High School in Littleton, Colorado armed with a variety of firearms managed to kill 15 persons and injure many others in their school. Following this incident, a wave of bomb threats to schools throughout the country erupted and several adolescents and adults were arrested. Ten days following the incident we surveyed a total of 412 students from urban area high schools. All students have heard of the shooting, $80 \%$ felt sad about the incident, $90 \%$ felt hate for the shooters and sad for the victims. $3 \%$ felt indifferent and $3 \%$ liked or admired the shooters. $60 \%$ thought the shooters had help from others. In response to why did the shooters do it, the top factors included loneliness, family problems and desire for attention. Virtually all participants thought that access to fire arms is what made it possible for these teens to commit their shooting. Other factors included poor school security, help from others and inattention from other students and teachers. The survey also included questions regarding suicide, carrying weapons and access to firearms. Adolescent violence continues to increase in the USA and other countries. Major contributing factors, at least from the adolescent point of view, are
\end{abstract}

\footnotetext{
Address all correspondence and reprint requests to:

Hatim A. Omar, MD,

Director, Adolescent Medicine, University of Kentucky, Department of Pediatrics, J453, Kentucky Clinic, Lexington, KY 40536-0284, USA Office:(606) 323-6426 ext. 307; Home: (606) 881-5813; Fax:(606) 257-7706 E-mail:haomar2@pop.uky.edu
} 
access to guns, family problems, lack of friends and poor com munication with teachers.

\section{INTRODUCTION}

Homicide rates in the United States are the highest of any developed country and adolescents are at the highest risk of violent death $/ 1 /$. Violent death from homicide and suicide among school-aged children more than doubled during the last decade $2,3 /$. By the mid-nineties, school-associated violence became widely recognized as a common and increasing problem 14-6/. In a two-year period (1992-1994) there were 105 school-associated violent deaths in the United States $17 /$. This trend of school-associated violence continues to rise. On April $20^{\text {th }}$, 1999 two high school students from Columbine High School in Littleton, Colorado armed with a variety of fire arms, managed to kill 15 persons and injure many others in that school. This incident triggered a wave of bomb threats to many schools throughout the country that led to widespread fear and many cases of school evacuations. This study was conducted 10 days following the Columbine incident. The objective was to survey high school students regarding school violence at a time when they are thinking about it, in order to understand their perception of the causes of violence and factors contributing to it.

\section{METHODS}

A survey of high school students from two high schools in the Lexington, $\mathrm{KY}$ area was conducted by having the students fill out an anonymous survey. The survey included biographical data section and questions regarding the Columbine High School incident. Students were asked if they have heard about the incident, their feelings about the shooting, the shooters and the victims. Reasons for the shooting, what made it possible and if the shooters acted alone. Another section of the survey inquired about personal experiences with weapons in school and at home, if they have thought or attempted hurting themselves or others and if they have ever been in a fight in which a weapon was used.

A total of 412 students ages $15-17$ completed the survey. Percentages were calculated for the different answers. 


\section{RESULTS}

Of the 412 students, 208 were females and 204 males. A total of 312 identified themselves as White, 12 Hispanics, 80 African-Americans and 8 Asians. All 412 students were aware of the Columbine incident. $80 \%$ of respondents felt sad about the shooting, $16 \%$ were disgusted, $13 \%$ outraged and $3 \%$ indifferent. $90 \%$ hated the shooters, $2 \%$ liked them, $1 \%$ admired them and $6 \%$ were indifferent. $90 \%$ felt sad about the victims, $9 \%$ were sorry about them and $1 \%$ were indifferent. $60 \%$ of the participants thought the shooters did not act alone. When asked there opinion why did these teens do the shooting, $90 \%$ thought they must have had problems with their families, $80 \%$ thought the shooters were lonely, $60 \%$ thought they wanted attention. Other answers included: They hated people $40 \%$, they could not make friends $30 \%$, they belonged to a violent hate gang $10 \%$ and having guns $2 \%$. All participants $(100 \%)$ thought that having access to firearms made it possible for the teens to do the shooting. Other factors that made it possible included: poor school security $90 \%$, help from others $60 \%$, inattention from other students $60 \%$ and inattention from teachers $60 \%$.

Responses to general questions relating to violence are shown in table $\mathbf{l}$.

\section{DISCUSSION}

This study was conducted in the aftermath of one of the worst school-associated violent incidents in the history of the United States. High school students were still thinking about the incident and what led to it and were eager to share their opinions. This may be an advantage in this survey in terms of obtaining honest answers from willing teens. However, the subjective nature of the responses is the main limitation of the study. While most students felt sad or outraged by the incident, a few were indifferent and some actually liked $(2 \%)$ or admired $(1 \%)$ the shooters. Even in a small total number of 412 students, that amounts to 12 students who would potentially encourage or copy the actions of the shooters. Should these numbers hold true for the nation, it would be easy to understand the seriousness of the issue of school violence. Most participants rated family problems and loneliness as the leading cause for the teens to commit the shooting. Despite the continuing rhetoric of politicians and the National Rifle Association that guns do not kill, virtually all participants believe that access to firearms made the killing 


\section{TABLE I}

Responses of high school students to general questions regarding violence

\begin{tabular}{lllc}
\hline & YES & NO & NOT SURE \\
\hline Ever seen a student carrying & $87 \%$ & $13 \%$ & $0 \%$
\end{tabular}

weapon to School?

Ever carried weapon

$36 \%$

$64 \%$

$0 \%$

to School?

Is there a firearm

$48 \%$

$50 \%$

$2 \%$

at your home?

Did any of your friends

$3 \%$

$92 \%$

$5 \%$

ever talk about hurting people?

Did you ever think

$2 \%$

$96 \%$

$2 \%$

about hurting people?

Ever think about

$42 \%$

$57 \%$

$1 \%$

hurting yourself.

Ever attempt to

$29 \%$

$71 \%$

$0 \%$

hurt yourself.

Ever been in a

$26 \%$

$74 \%$

$0 \%$

fight with weapon.

possible. Adolescents lack well-developed abstract thinking, therefore they can not appreciably foresee the finality and long-term consequences of their actions. That makes access to firearms the more dangerous. Most participants have seen weapons in their schools and have firearms in their homes. Significant number of the respondents have thought about or attempted hurting themselves or have been into a fight with use of a weapon. That adds to the concern that the potential for violence is fairly high among high school students. 
Although school-associated violence accounts for less than $1 \%$ of homicides and suicides among school-aged children in the United States $/ 7$, its impact is disproportionately higher because of the media attention generated and the sensitivity of parents and the rest of society to what happens in the schools. All this brings the issue of prevention to forefront of measures to combat school violence. Strategies to prevent or reduce violence in the school setting have been suggested by many educators and public health officials $/ 5,8-12 /$. Unfortunately, none of these strategies has been objectively proven to work. Most deaths identified in a study of violent school-associated violence $/ 7 /$ resulted from firearms, further showing the desperate need for measures to prevent teens from access to these weapons.

We believe that the responses given by high school students in this study, highlight the facts that family problems, poor communication with families, peers and teachers, lack of friends and most importantly access to firearms are leading factors in the continued rise in school associated violence. Parent education, community-based after school programs and restricting access to firearms are feasible measures in the effort to reduce school-associated violence.

\section{REFERENCES}

1. Sege RD. Adolesc Health Update. 1999;12(1).

2. Centers for Disease Control and Prevention. Homicides among 15-19-year-old males-United States, 1963-1991. MMWR Morb Mortal Wkly Rep. 1994;43:725-727.

3. Centers for Disease Control and Prevention. Suicide among children, adolescents and young adults- United States, 1980-1992. MMWR Morb Mortal Wkly Rep. 1995;44:289-291.

4. Sheley JF, McGee ZT, Wright JD. Gun-related violence in and around inner-city schools. Am J Dis Child. 1992;146:677-682.

5. National School Board Association. Violence in the Schools: How America's school Boards Are Safeguarding Our Children. Alexandria, VA: National School Boards Association; 1993.

6. National League of Cities. School Violence in America's Cities: NLC Survey Overview. Washington, DC: National League of Cities; 1993.

7. Kachur SP, Stennies GM, Pôwell KE et Al. School-Associated violent deaths in the United States, 1992 to 1994. JAMA. 1996;275:1729-1733. 
8. Reaching the Goals: Goal Six: Safe, Disciplined, and Drug-Free Schools. Washington, DC: Office of Educational Research and Improvement, US Dept of Education; 1993.

9. Furlong M, Morrison R, Clontz D. Planning principles for safe schools. School Safety. Spring 1993:23-27.

10. Virginia Association of School Superintendents. Violence in Schools: Recommendations for Action by the Education Summit. Charlottesville: Virginia Association of School Superintendents; 1992.

11. National Center for Injury Prevention and Control. The Prevention of Youth Violence: A Frame-work for Community Action. Atlanta, GA: Centers for Disease Control and prevention; 1993

12. Kachur SP, Potter LB, Powell KE, Rosenberg ML. Suicide: epidemiology, prevention, treatment. Adolesc Med State Art Rev. 1995;6:171-182. 